$$
-
$$




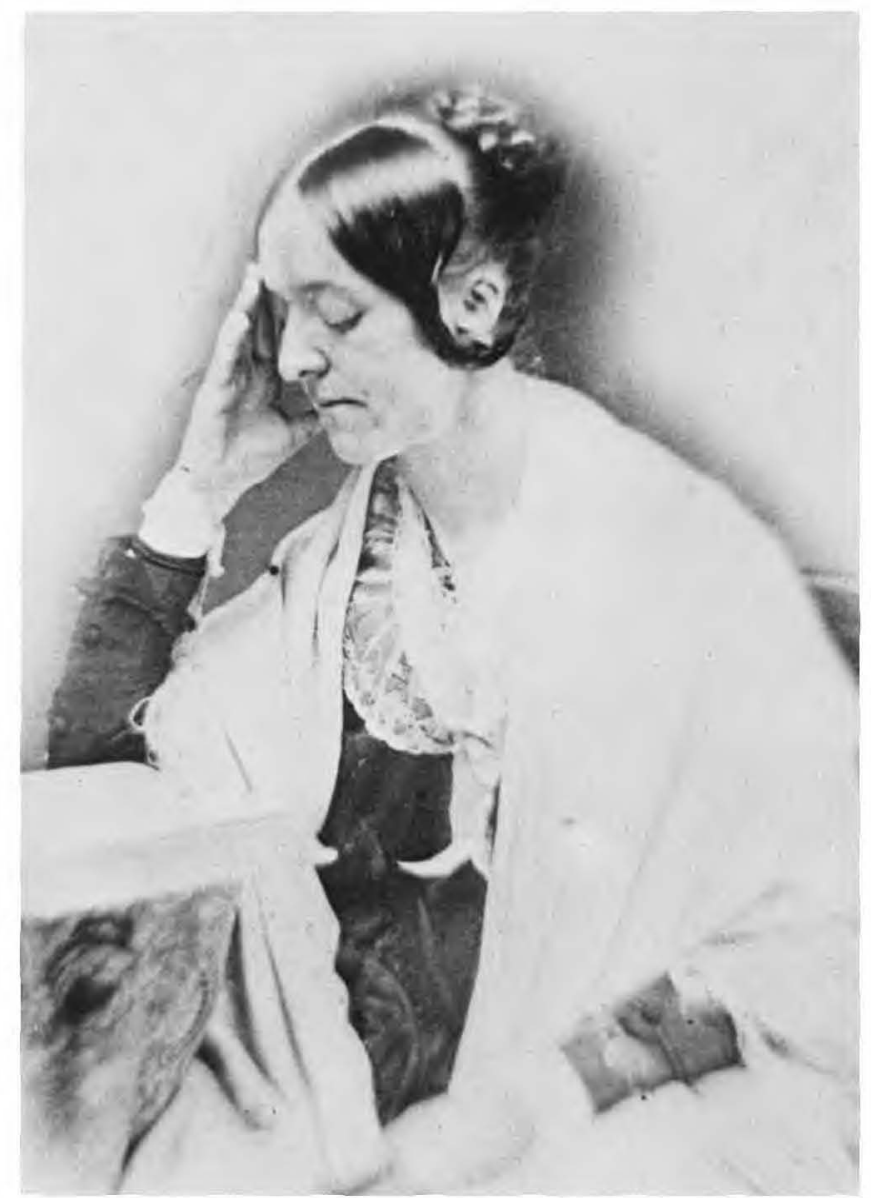

Margaret Fuller. Daguerreotype, 1846 . Courtesy of the Metropolitan Museum of Art, gift of I. N. Phelps Stokes, Edward S. Hawes, Alice Mary Hawes, Marion Augusta Hawes, 1937; and the Schlesinger Library, Radcliffe College. 


\section{THE LETTERS OF \\ Margaret Fuller}

Edited by

ROBERT N. HUDSPETH

VOLUME I $1817-38$

qp

Cornell University Press

ITHAC:A AND LONDON 
PUBLICATION OF THIS BOOK WAS ASSISTED BY A GRANT FROM THE PUBLICATIONS PROGRAM OF THE NATIONAL ENDOWMENT FOR THE HUMANITIES, AN INDEPENDENT FEDERAL AGENCY.

Copyright $\mathbb{C} 1983$ by Cornell University Press

All rights reserved. Except for brief quotations in a review, this book, or parts thereof, must not be reproduced in any form without permission in writing from the publisher. For information address Cornell University Press, 124 Roberts Place, Ithaca, New York $14^{8} 5^{\circ}$.

First published 1983 by Cornell University Press.

Second printing 1992 .

International Standard Book Number o-8014-1386-9 Library of Congress Catalog Card Number 82-22098

Printed in the United States of America

Librarians: Library of Congress cataloging information appears on the last page of the book.

The paper in this book meets the minimum requirements of the American National Standard for Information Sciences-Permanence of Paper for Printed Library Materials, ANSI Z39.48-1984. 
To the memory of my son Robert Neal Hudspeth, Jr. 
